\title{
Avanços na compreensão do paladar
}

\author{
Jorge Faber*
}

Foi o processo de desenvolvimento da civilização que trouxe consigo a ascensão do preparo dos alimentos e a atenção ao paladar do nível rudimentar para o atual. A princípio, a função do paladar é permitir que animais obtenham informações valiosas a respeito da natureza e qualidade dos alimentos, evitando os que oferecem risco à vida e optando pelos calóricos e nutritivos. Mas a abundância de alimentos nas cidades de certas regiões do mundo propiciou sofisticação no preparo dos pratos, por ter deflagrado uma busca de sabores apetitosos, equilibrados e surpreendentes.

O progresso da culinária foi acompanhado pelo da curiosidade científica acerca dos mecanismos biológicos que envolvem os prazeres da mesa.

\section{Percepção dos sabores}

Mamíferos podem perceber e responder a um grande repertório de entidades químicas, incluindo açúcares, sais, ácidos, aminoácidos e ampla variedade de substâncias tóxicas amargas. É interessante notar que durante muito tempo pensou-se ser a língua setorizada quanto à percepção gustativa. Inclusive, testes neurológicos foram desenvolvidos baseados na falsa premissa que botões gustativos específicos para determinados sabores se concentravam em certas regiões da língua. A bem da verdade, eles estão dissipados aleatoriamente pelo dorso da língua e pelo palato, e se apresentam em menor número em outras regiões.

São as células dos botões gustativos as responsáveis por "perceber" os sabores. O doce, o amargo e o umami são percebidos por meio de receptores de membrana. Em contrapartida, o salgado e o ácido dependem de canais iônicos especializados de $\mathrm{Na}+$ e $\mathrm{H}+$. Umami é o sabor - único que certos aminoácidos apresentam.

Vários receptores já foram identificados, pertencendo às famílias de receptores acoplados à proteína $\mathrm{G}$, uma proteína de membrana ${ }^{3}$. Eles, que também são proteínas, recebem em sua denominação duas letras: TR. Elas identificam a função da molécula e são abreviaturas, no inglês, de taste receptor (receptor do sabor).

Essas estruturas iniciam sua ação, resumidamente, pela ligação de uma molécula, tal como a glicose. Ela promove alteração conformacional do receptor, desencadeando a transdução do sinal pelo citoplasma. Nesse sistema, a ativação do receptor leva à liberação de íons de cálcio proveniente de reservatórios internos à célula e estes sinalizam para terminações nervosas a percepção gustativa, sendo a mensagem interpretada como um sabor.

Mais de 30 receptores T2Rs já foram associados ao discernimento do sabor amargo. Essas estruturas podem apresentar diferenças entre espécies - tal como homem e camundongo - e isso determina a disparidade de comportamento na seleção de alimentos com esse sabor ${ }^{2}$.

Por sua vez, receptores T1Rs respondem à maioria dos 20 aminoácidos básicos. Estes merecem destaque porque L-aminoácidos funcionam como tijolos na construção das proteínas, como precursores biosintéticos de muitas moléculas biologicamente relevantes, e como combustível metabólico. Entretanto, poucos aminoácidos, assim como o L-glutamato, possuem o sabor umami. Alguns são doces e outros neutros ou amargos ${ }^{3}$.

Os receptores para cada sabor são expressos, predominantemente, em um tipo celular. Isso quer dizer que há células especializadas na percepção dos diferentes sabores. Quando camundongos transgênicos são gerados com receptores para amargo em células especializadas em doce, os animais passam a ter preferência por alimentos amargos, e o contrário também é verdadeiro ${ }^{2}$.

\section{O impacto da temperatura na percepção dos sabores}

$\mathrm{O}$ aquecimento ou resfriamento de áreas da língua podem levar a sensações gustativas tanto na região anterior quanto posterior do órgão. A diminuição da temperatura evoca o sabor azedo, embora uma parcela menor de indivíduos perceba também o salgado. Já o aumento é percebido, transitoriamente, como uma sensação de doçura ${ }^{1}$. Recentemente, foi demonstrado que essas sensações são frutos da estimulação direta de receptores ou de canais iônicos nas membranas celulares ${ }^{4}$. Isso significa, por exemplo, que o consumo de um mesmo chocolate em diferentes temperaturas acarreta experiências gustativas distintas. Quanto mais quente estiver o chocolate, mais doce ele parecerá.

Em suma, a complexidade da percepção do paladar é ainda aumentada pela interação com a temperatura. Muito ainda há que se estudar antes de possuirmos respostas para vários dos mecanismos moleculares do paladar. Antes disso, podemos também nos ater a questionamentos mais simples: qual a temperatura ideal para se apreciar um Vinho-do-Porto safrado?

1. CRUZ, A. GREEN, B. Thermal stimulation of taste. Nature London, v. 403, no. 24, p. 889-892, Feb. 2000.

2. MUELLER, K. L. et al. The receptors and coding logic for bitter taste. Nature, London, v. 434, no. 10, p. 225- 229, Mar. 2005.

3. NELSON, G. et al. An amino-acid taste receptor. Nature, London, v. 416, no. 14, p. 199-202, Mar. 2002.

4. TALAVERA, $K$. et al. Heat activation of TRPM5 underlies thermal sensitivity of sweet taste. Nature, London, v. 438, no. 15, p. 1022-25, Dec. 2005

\footnotetext{
* Doutor em Biologia - Morfologia, Laboratório de Microscopia Eletrônica da Universidade de Brasília, Mestre em Ortodontia pela

Universidade Federal do Rio de Janeiro, Clínica privada focada no atendimento de pacientes adultos.
} 